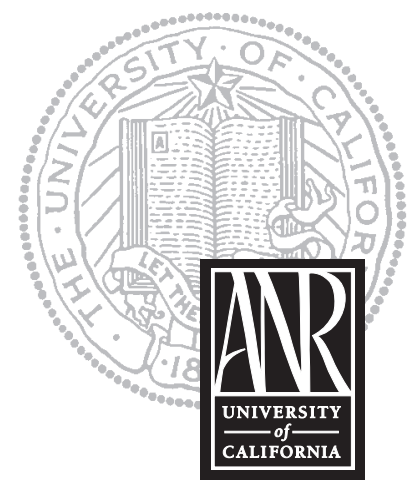

UNIVERSITY OF CALIFORNIA

Division of Agriculture and Natural Resources

http://anrcatalog.ucdavis.edu
PUBLICATION $\mathbf{8 0 0 9}$

\section{Interpreting Turfgrass Irrigation Water Test Results}

M. ALI HARIVANDI, Environmental Horticulture Advisor, Alameda, Contra Costa, and Santa Clara Counties

$\mathbf{T}$ he notion that water quality problems caused by soluble salts arise only-or even primarily - in regions with arid climates is far from the truth. For example, the excessive pumping of fresh water from wells in coastal areas can lead to saltwater intrusion problems. Even in high-rainfall areas the groundwater may contain significant levels of soluble salts derived from underground rock formations of marine origin. Moreover, increasing numbers of golf courses, parks, cemeteries, school campuses, industrial, and commercial turfed sites use potentially saline recycled municipal water for irrigation. The result of this breadth of use is that the effects of excess soluble salts are visible on turfgrass plantings in a wide range of climates. Water analysis and periodic monitoring have thus become key components of sound irrigation management.

Water analysis by a commercial laboratory provides data on many parameters, some of which are of little significance for turfgrass irrigation. The most important parameters for turfgrass management are total concentration of soluble salts (salinity); sodium ( $\mathrm{Na}$ ) content; relative proportion of sodium to calcium ( $\mathrm{Ca}$ ) and magnesium (Mg) (Sodium Adsorption Ratio or SAR); chloride (Cl), boron (B), bicarbonate $\left(\mathrm{HCO}_{3}\right)$, and carbonate $\left(\mathrm{CO}_{3}\right)$ content; and $\mathrm{pH}$. Other parameters that you are likely to find on a water test report and that you should review are nutrient content (nitrogen, phosphorus, and potassium), chlorine content, suspended solids, and turbidity, though none of these by itself plays a major role in determining the suitability of water for irrigation.

\section{IMPORTANT TEST PARAMETERS}

Salinity. All irrigation waters contain some dissolved mineral salts and chemicals. Some soluble salts are identified as nutrients and are beneficial to turfgrass growth; others may be phytotoxic or may become so when present in high concentrations. The rate at which salts accumulate to undesirable levels in a soil depends on their concentration in the irrigation water, the amount of water applied annually, annual precipitation (rain plus snow), and the soil's physical and chemical characteristics.

Different laboratories report water salinity in different ways: as Total Dissolved Solids (TDS) measured in parts per million (ppm) or milligrams per liter ( $\mathrm{mg} / \mathrm{L})$, or as electrical conductivity (ECW) measured in millimhos per centimeter $(\mathrm{mmhos} / \mathrm{cm})$, micromhos per centimeter $(\mu \mathrm{mhos} / \mathrm{cm})$, decisiemens per meter $(\mathrm{dS} / \mathrm{m})$, or siemens per meter $(\mathrm{S} / \mathrm{m})$. Some labs may also report the individual components of salinity (e.g., sodium) in milliequivalents per liter (meq/L). You can use the following equations to convert results from one set of units to another, and so compare data from differently formatted reports:
(1) $1 \mathrm{ppm}=1 \mathrm{mg} / \mathrm{L}$
(2) $1 \mathrm{mg} / \mathrm{L}=\mathrm{meq} / \mathrm{L} \times$ Equivalent Weight (see Table 1)
(3) $1 \mathrm{mmho} / \mathrm{cm}=1 \mathrm{dS} / \mathrm{m}=1,000 \mu \mathrm{mhos} / \mathrm{cm}=0.1 \mathrm{~S} / \mathrm{m}$ 
Table 1. Conversion factors for $\mathrm{mg} / \mathrm{L}$ and $\mathrm{meq} / \mathrm{L}$

\begin{tabular}{lcc}
\hline Constituent & $\begin{array}{c}\text { To convert } \\
\text { mg/L to meq/L } \\
\text { multiply by }\end{array}$ & $\begin{array}{c}\text { To convert } \\
\text { meq/L to } \mathbf{~ m g} / \mathbf{L} \\
\text { multiply by }\end{array}$ \\
\hline Sodium $(\mathrm{Na})$ & 0.043 & 23 \\
Calcium $(\mathrm{Ca})$ & 0.050 & 20 \\
Magnesium $(\mathrm{Mg})$ & 0.083 & 12 \\
Bicarbonate $\left(\mathrm{HCO}_{3}\right)$ & 0.016 & 61 \\
Carbonate $\left(\mathrm{CO}_{3}\right)$ & 0.033 & 30 \\
Chloride $(\mathrm{Cl})$ & 0.029 & 35 \\
\hline
\end{tabular}

Historically, laboratories determine TDS in water by evaporating a known volume and then weighing any precipitate. Results of this method were reported as ppm or $\mathrm{mg} / \mathrm{L}$. This process is time-consuming, and today the preferred method for assessment of soluble salt content is the measurement of electrical conductivity (ECW), which is directly related to the salt content of the water. Regardless of how salinity is reported, the relationship between ECW and TDS is approximately

\section{(4) $\mathrm{ECw}(\mathrm{mmhos} / \mathrm{cm}$ or $\mathrm{dS} / \mathrm{m}) \times 640=\mathrm{TDS}(\mathrm{ppm}$ or $\mathrm{mg} / \mathrm{L})$}

Note that the 640 value is a general average factor and may require adjustment in special circumstances. For example, waters containing substantial amounts of sulfate require a higher conversion factor. Many low-salinity groundwater supplies along coastal valleys of California have water that would fall within this category. Sometimes the appropriate conversion factor can be as high as 700. If you are unsure about which conversion factor to use, consult the testing laboratory.

Most water that is acceptable for turfgrass irrigation contains from 200 to 800 ppm soluble salts. Soluble salt levels greater than 2,000 ppm may injure turfgrass; salt levels up to 2,000 ppm may be tolerated by some turfgrass species (Table 2), but only on soils with exceptional permeability and subsoil drainage. Good permeability and drainage allow a turfgrass manager to leach excessive salts from the root zone by periodically applying heavy irrigations. Sand-based sport fields and golf greens have the proper soil structure for this form of salinity management. (It should be noted that irrigation water with a very low salt content [i.e., below $0.2 \mathrm{dS} / \mathrm{m}$ ] can actually reduce the permeability of a soil. Such water can disperse clay particles, which then clog large soil pores that are important for good permeability.)

Table 2. Relative tolerances of California turfgrass species to soil salinity (ECe)

\begin{tabular}{|c|c|c|c|}
\hline $\begin{array}{l}\text { Sensitive } \\
(<3 \mathrm{dS} / \mathrm{m})\end{array}$ & $\begin{array}{l}\text { Moderately } \\
\text { sensitive } \\
\text { (3 to } 6 \mathrm{dS} / \mathrm{m} \text { ) }\end{array}$ & $\begin{array}{l}\text { Moderately } \\
\text { tolerant } \\
\text { ( } 6 \text { to } 10 \mathrm{dS} / \mathrm{m} \text { ) }\end{array}$ & $\begin{array}{l}\text { Tolerant } \\
\text { (>10 dS/m) }\end{array}$ \\
\hline Annual bluegrass & Annual ryegrass & Perennial ryegrass & Alkaligrass \\
\hline Colonial bentgrass & Creeping bentgrass & Tall fescue & Bermudagrasses \\
\hline Kentucky bluegrass & Fine-leaf fescues & Zoysiagrasses & Seashore paspalum \\
\hline Rough bluegrass & Buffalograss & & St. Augustinegrass \\
\hline
\end{tabular}

From: M. A. Harivandi, J. D. Butler, and L. Wu. 1992. Salinity and turfgrass culture. In D. V. Waddington, R. N. Carrow, and R. C. Shearman (eds.) Turfgrass, pp.207-229. Series No. 32. Madison: American Society of Agronomy. 
Table 3 lists the parameters a turfgrass manager should consider in evaluating irrigation water quality. As indicated, waters with $\mathrm{EC}$ w values greater than $0.7 \mathrm{dS} / \mathrm{m}$ ( $450 \mathrm{mg} / \mathrm{L})$ present increased salinity problems. Only careful management will prevent the accumulation of deleterious amounts of salts in the soil if water with a high $\mathrm{ECw}$ is used for irrigation. Avoid using any water with an ECw above $3 \mathrm{dS} / \mathrm{m}$.

The salt tolerance of turfgrass and other plants is expressed in terms of the salt content of the soil root zone. For example, as indicated in Table 2 Kentucky bluegrass will tolerate a soil salinity (ECe, the electrical conductivity of the soil water extract) of up to $3 \mathrm{dS} / \mathrm{m}$. You must therefore consider soil physical characteristics and drainage, both of them important factors in determining root zone salinity, when you decide about the suitability of a given irrigation water. Water with an ECw of $1.5 \mathrm{dS} / \mathrm{m}$ may be suitable for grass grown on sandy soil with good drainage (and thus high natural leaching), but the same water may prove injurious within a very short period if used to irrigate the same grass grown on a clay soil or a soil with limited drainage resulting from salt buildup in the root zone.

Table 3. Guidelines for the interpretation of water quality for irrigation

\begin{tabular}{|c|c|c|c|c|}
\hline \multirow[b]{2}{*}{$\begin{array}{l}\text { Potential } \\
\text { irrigation problem }\end{array}$} & \multirow[b]{2}{*}{$\begin{array}{l}\text { Unit of } \\
\text { measure }\end{array}$} & \multicolumn{3}{|c|}{ Degree of restriction on use } \\
\hline & & None & $\begin{array}{l}\text { Slight to } \\
\text { moderate }\end{array}$ & Severe \\
\hline \multicolumn{5}{|l|}{ Salinity } \\
\hline $\mathrm{ECW}$ & $\mathrm{dS} / \mathrm{m}$ & $<0.7$ & 0.7 to 3.0 & $>3.0$ \\
\hline TDS & $\mathrm{mg} / \mathrm{L}$ & $<450$ & 450 to 2,000 & $>2,000$ \\
\hline \multicolumn{5}{|l|}{$\begin{array}{l}\text { Soil water infiltration } \\
\quad \text { (evaluate using ECw }[\mathrm{dS} / \mathrm{m}] \text { and }\end{array}$} \\
\hline if $\mathrm{SAR}=0$ to $3 \& \mathrm{ECW}=$ & & $>0.7$ & 0.7 to 0.2 & $<0.2$ \\
\hline if $\mathrm{SAR}=3$ to $6 \& \mathrm{ECW}=$ & & $>1.2$ & 1.2 to 0.3 & $<0.3$ \\
\hline if $\mathrm{SAR}=6$ to $12 \& \mathrm{ECW}=$ & & $>1.9$ & 1.9 to 0.5 & $<0.5$ \\
\hline if $\mathrm{SAR}=12$ to $20 \& \mathrm{ECW}=$ & & $>2.9$ & 2.9 to 1.3 & $<1.3$ \\
\hline if $\mathrm{SAR}=20$ to $40 \& \mathrm{ECW}=$ & & $>5.0$ & 5.0 to 2.9 & $<2.9$ \\
\hline \multicolumn{5}{|l|}{ Specific ion toxicity } \\
\hline root absorption & SAR & $<3$ & 3 to 9 & $>9$ \\
\hline foliar absorption & $\mathrm{meq} / \mathrm{L}$ & $<3$ & $>3$ & - \\
\hline & $\mathrm{mg} / \mathrm{L}$ & $<70$ & $>70$ & - \\
\hline \multicolumn{5}{|l|}{ Chloride (Cl) } \\
\hline \multirow[t]{2}{*}{ root absorption } & $\mathrm{meq} / \mathrm{L}$ & $<2$ & 2 to 10 & $>10$ \\
\hline & $\mathrm{mg} / \mathrm{L}$ & $<70$ & 70 to 355 & $>355$ \\
\hline \multirow[t]{2}{*}{ foliar absorption } & $\mathrm{meq} / \mathrm{L}$ & $<3$ & $>3$ & - \\
\hline & $\mathrm{mg} / \mathrm{L}$ & $<100$ & $>100$ & - \\
\hline Boron (B) & $\mathrm{mg} / \mathrm{L}$ & $<1.0$ & 1.0 to 2.0 & $>2.0$ \\
\hline \multicolumn{5}{|l|}{ Miscellaneous effects } \\
\hline Bicarbonate $\left(\mathrm{HCO}_{3}\right)$ & $\mathrm{meq} / \mathrm{L}$ & $<1.5$ & 1.5 to 8.5 & $>8.5$ \\
\hline (unsightly foliar deposits) & $\mathrm{mg} / \mathrm{L}$ & $<90$ & 90 to 500 & $>500$ \\
\hline $\mathrm{pH}$ & & normal range & 6.5 to 8.4 & \\
\hline Residual chlorine $\left(\mathrm{Cl}_{2}\right)$ & $\mathrm{mg} / \mathrm{L}$ & $<1.0$ & 1 to 5 & $>5$ \\
\hline
\end{tabular}

Adapted from D. W. Westcot and R. S. Ayers. 1984. Irrigation water quality criteria. In G. S. Pettygrove and T. Asano (eds.) Irrigation with Reclaimed Municipal Wastewater - A guidance manual. Report No. 841-1wr. California State Water Resources Control Board, Sacramento, CA; and from D. S. Farnham et al. 1985. Water Quality: Its Effects on Ornamental Plants. University of California Division of Agriculture and Natural Resources Publication 2995. 
The figures in Table 2 give a general guide to the salt tolerance of individual turfgrasses. As indicated, soils with ECe values below $3 \mathrm{dS} / \mathrm{m}$ are considered satisfactory for most turfgrasses. ECe values between 3 and $10 \mathrm{dS} / \mathrm{m}$ indicate soils in which only a few salt-tolerant turfgrass species can survive.

Sodium. Sodium content is another important factor in irrigation water quality evaluation. Plant roots absorb sodium and transport it to leaves where it can accumulate and cause injury. The leaf symptoms of sodium toxicity resemble those of salt burn. Because salts can be absorbed directly by leaves, irrigation water with a high level of sodium salts can be particularly toxic if applied to plant leaves via overhead sprinklers. Sodium toxicity is often of more concern on plants other than turfgrasses, primarily because accumulated sodium is removed every time grass is mowed. Among grasses grown on golf courses, annual bluegrass and bentgrass are the most susceptible to sodium phytotoxicity. In these cases, mowing may not provide protection since these grasses are generally cut very short (a stress in itself), and any sodium accumulation will then make up a large proportion of the small remaining quantity of leaf tissue.

The data in Table 3 provide general guidelines for assessing the effect of sodium in irrigation water. As indicated in the table, the level of sodium tolerated by nonturf plants varies with irrigation application method. Most landscape plants will tolerate as much as 70 ppm (mg/L) sodium when irrigated by overhead sprinkler.

SAR (Sodium Adsorption Ratio). Although sodium in the irrigation water can be toxic to plants, a more common deleterious effect of sodium results from its effect on soil structure. This effect generally is of more concern to golf course superintendents and other professional managers of intensely used turfgrassess.

When irrigation is applied to the soil, the best indicator of sodium effect is a water's Sodium Adsorption Ratio (SAR), a value which should be provided in all laboratory water analyses. As a general rule, water with an SAR value below 3 is considered safe for turf and other ornamental plants (Table 3). Because SAR is such an important factor in water evaluation, however, it merits a thorough understanding.

The high sodium content common to recycled water can cause deflocculation (breakdown) of soil clay particles, severely reducing soil aeration and water infiltration and percolation. In other words, a soil's permeability is reduced by irrigation with water high in sodium. The best measure of a water's likely effect on soil permeability is the water's SAR considered together with its ECW. SAR is the ratio of the concentration of sodium ions to the concentration of calcium plus magnesium. You can use the formula below to calculate SAR if a laboratory report does not provide it but does provide values for sodium, calcium, and magnesium in meq/L. If values are provided as $\mathrm{mg} / \mathrm{L}$ or ppm, convert them to $\mathrm{meq} / \mathrm{L}$ using the conversion factors in Table 1 before you use the formula.

$$
\mathrm{SAR}=\frac{\mathrm{Na}}{\sqrt{(\mathrm{Ca}+\mathrm{Mg}) \div 2}}
$$

Generally, water with an SAR greater than 9 can cause severe permeability problems when applied to fine-textured (clay) soils over a period of time. Coarse-textured (sandy) soils have fewer permeability problems and can tolerate an SAR of this magnitude. For example, you can successfully irrigate golf greens and sports fields constructed with high-sand-content root zone mixes using high-SAR water because of their good drainage.

For waters high in bicarbonate, some laboratories adjust the calculation of SAR (yielding an "adjusted SAR" or "Adj. SAR") because soil calcium and magnesium 
concentrations are affected by the water's bicarbonate. In simplest terms, Adj. SAR reflects the water's calcium, magnesium, sodium, and bicarbonate content as well as its total salinity. Other labs use a newer method to adjust the SAR value and report the adjusted value as Adj. $\mathrm{R}_{\mathrm{Na}}$. Not all labs have adopted this new method, which adjusts the SAR to account for either the precipitation or dissolution of calcium carbonate, but the unadjusted SAR value is sufficient for our purposes.

Interaction of salinity and SAR. Salts and sodium do not act independently in the plant environment. The effects of sodium on soil particle dispersion (and therefore permeability) are counteracted by a high electrolyte (soluble salts) concentration; therefore, one cannot assess a water's sodium hazard independent of its salinity. The combined effect of water ECW and SAR on soil permeability is given in Table 3. Note that the table provides general guidelines only. Soil properties, irrigation manage ment, climate, a given plant's salt tolerance, and cultural practices all interact significantly with water quality in the actual behavior of soils and plant growth.

Bicarbonate and carbonate. The bicarbonate content and, to a lesser degree, the carbonate content of irrigation water also deserve careful evaluation. Recycled waters and well waters are especially likely to contain excessive bicarbonate levels. Substantial bicarbonate levels in irrigation water can increase soil pH, and in combination with carbonate they may affect soil permeability. In addition, bicarbonate content may make itself obvious during hot, dry periods, when evaporation may cause white lime $\left(\mathrm{CaCO}_{3}\right)$ deposits to appear on leaves of plants irrigated by overhead sprinklers.

Although high levels of bicarbonate in water can raise soil pH to undesirable levels, bicarbonate's negative impact on soil permeability is often of greater concern. As mentioned above, the bicarbonate ion may combine with calcium or magnesium and precipitate as calcium carbonate or magnesium carbonate. This precipitation increases the SAR in the soil solution because it lowers the dissolved calcium concentration.

Table 3 indicates tolerable levels of bicarbonate in irrigation waters. The bicarbonate hazard of water may be express as Residual Sodium Carbonate (RSC), calculated thus

$$
\mathrm{RSC}=\left(\mathrm{HCO}_{3}+\mathrm{CO}_{3}\right)-(\mathrm{Ca}+\mathrm{Mg})
$$

where concentrations of ions are expressed in meq/L (see Equation 2 and Table 1 for conversions). Generally, water with an RSC value of $1.25 \mathrm{meq} / \mathrm{L}$ or lower is safe for irrigation, water with an RSC between 1.25 and $2.5 \mathrm{meq} / \mathrm{L}$ is marginal, and water with an RSC of $2.5 \mathrm{meq} / \mathrm{L}$ or more is probably not suitable for irrigation.

pH (hydrogen ion activity). The $\mathrm{pH}$ is a measure of water's acidity or alkalinity measured in $\mathrm{pH}$ units. The scale ranges from 0 to 14, with $\mathrm{pH} 7$ representing neutral-water with a $\mathrm{pH}$ of 7 is neither acidic nor alkaline. As it progresses from $\mathrm{pH} 7$ to $\mathrm{pH} 0$, water becomes increasingly acidic; from $\mathrm{pH} 7$ to $\mathrm{pH} 14$, water becomes increasingly basic (alkaline). The $\mathrm{pH}$ units are on a logarithmic scale: there is a tenfold change between each whole $\mathrm{pH}$ number. Thus a water with $\mathrm{pH} 8$ is 10 times more basic than a water with $\mathrm{pH} \mathrm{7,} \mathrm{and} 100$ times more basic than a water with $\mathrm{pH}$ 6 . Water $\mathrm{pH}$ is easy to determine and provides useful information about the water's chemical properties. Although seldom a problem in itself, a very high or very low water $\mathrm{pH}$ can be a warning that you need to evaluate the water for other constituents. The desirable soil pH for most turfgrasses ranges from 5.5 to 7.0; most irrigation waters' pH values, however, range from 6.5 to 8.4. Depending on the proper- 
ties of the soil where the grass is grown, an irrigation water $\mathrm{pH}$ range of 6.5 to 7 would be most desirable. Water with a pH outside the desirable range must be carefully evaluated for other chemical constituents.

Chloride. Besides contributing to the total soluble salt concentration of irrigation water, chloride $(\mathrm{Cl})$ may be directly toxic to plants grown on a golf course, park, or other landscape site. Although chloride is not particularly toxic to turfgrasses, many trees, shrubs, and ground covers are quite sensitive to it.

Chloride is absorbed by plant roots and translocated to leaves where it accumulates. In sensitive plants this accumulation leads to necrosis: leaf margin scorch in minor cases, total leaf kill and abscission in severe cases. Similar symptoms may occur on sensitive plants if high-chloride water is applied via overhead sprinklers, since chloride can be absorbed by leaves as well as roots. Turfgrasses tolerate all but extremely high levels of chloride as long as they are regularly mowed.

Chloride salts are quite soluble, so they can be leached from well-drained soils with good subsurface drainage. As indicated in Table 3, irrigation water with a chloride content greater than $355 \mathrm{mg} / \mathrm{L}$ is toxic when absorbed by roots, while a chloride content greater than $100 \mathrm{mg} / \mathrm{L}$ can damage sensitive ornamental plants if applied to foliage.

Boron. Boron (B) is an essential micronutrient for plant growth, though it is required in very small amounts. Even at concentrations as low as 1 to $2 \mathrm{mg} / \mathrm{L}$ in irrigation water, it is phytotoxic to most ornamental plants and capable of causing leaf burn (Table 3). The most obvious symptoms appear as a dark necrosis on the margins of older leaves. Turfgrasses generally tolerate boron better than any other plants grown in a landscape, but they are more sensitive to boron toxicity than to either sodium or chloride. Most turfgrasses will grow in soils with boron levels as high as 10 ppm.

\section{OTHER PARAMETERS}

Chlorine. Irrigation water originating from municipal recycled water may contain excessive residual chlorine $\left(\mathrm{Cl}_{2}\right)$, a potential plant toxin. Chlorine toxicity is almost always associated only with recycled water sources, which are routinely disinfected with chlorine-containing compounds. Chlorine toxicity occurs only if high levels of chlorine are sprayed directly onto foliage, a situation likely to occur only if the recycled water goes straight from the treatment plant to an overhead irrigation system. Free chlorine is very unstable in water, and it will dissipate quickly if the water is stored for even a short period of time between treatment and application to plants. As indicated in Table 3, residual chlorine is of concern at levels above $5 \mathrm{mg} / \mathrm{L}$.

Nutrients. With the exception of municipal recycled water, the nutrient value of most irrigation waters is negligible. Recycled waters, however, always contain a range of micro (trace) elements sufficient to satisfy the needs of most turfgrasses. They may also contain enough macro (major) nutrients (nitrogen, phosphorus, and potassium) to figure significantly in the fertilization program of a large turfed area.

Most laboratories test recycled water for nutrient content, and many report nutrients in terms of "lb/acre-ft of water applied." The economic value of these nutrients can be substantial. Even where the quantities of nutrients are low, the nutrients can be used very efficiently by plants because they are applied on a regular basis. If the laboratory report does not include the lb/acre-ft of nutrients, you can use the following conversion formula to determine this value for any nutrient contained in the irrigation water:

$\mathrm{lb} /$ acre-ft of nutrient $=$ nutrient content $(\mathrm{mg} / \mathrm{L}$ or $\mathrm{ppm}) \times 2.72$ 
Suspended solids. The suspended solids (SS) in irrigation water are the inorganic particles such as clay, silt, and other soil constituents, as well as organic matter such as plant material, al gae, and bacteria. These materials do not dissolve in water and can thus be removed only by filtration, an essential step for most irrigation systems in which plugged sprinkler head openings or plugged valves can reduce a system's efficiency and life span.

The suspended solids in domestic municipal water sources are negligible and not a cause for concern. However, you should monitor suspended solids in well, lake, pond, canal, or recycled waters used for irrigation. Besides the mechanical problems they present for irrigation systems, suspended solids can seal a soil surface, especially on sand-based golf greens, sports fields, and other sandy media. Solids can fill in air spaces between sand particles, reducing infiltration and drainage and increasing compaction. Since these effects vary considerably with the type of suspended solid, the irrigation system, and the turfgrass soil, it is difficult to formulate general acceptable values for suspended solids in irrigation water. General consensus says that an SS level below $50 \mathrm{mg} / \mathrm{L}$ is safe for a drip irrigation system while values above $100 \mathrm{mg} / \mathrm{L}$ will cause plugging, but the complexity and variability of irrigation waters and systems make effective filtration the most sensible approach to controlling hazards posed by suspended solids.

Turbidity. Another factor, turbidity, measures the transmission of light through water with respect to matter suspended in the water. This measurement frequently appears in laboratory results, especially in analyses of recycled water, and it is an important tool in determining the quality of domestic and recycled water. It is not a useful tool for evaluating irrigation water, primarily because there are no uniform guidelines for acceptable turbidity values for irrigation water.

\section{SAMPLING IRRIGATION WATER}

The results of a laboratory water test are only as good-and therefore only as useful-as the water sample tested. Thus, a tested sample must be truly representative of the irrigation water applied. Poor or contaminated samples result in misleading evaluations. Since the few ounces of water finally tested represent a tiny fraction of the millions of gallons of water eventually used to irrigate a golf course, cemetery, or park, getting a good sample can be trickier than it may at first appear.

There are no strict rules for sampling water. Equal attention is due, however, to the sampling equipment, timing, location, and handling of the sample. Some laboratories provide instructions on what type of containers to use for sampling and the amount of water needed for a sample. If no instructions are available from the lab, use clean plastic bottles rather than glass since some glass bottles may be a source of boron. Also, plastic bottles reduce the chance of breakage during transfer. Always use a clean bottle; if unsure of its cleanliness, wash the bottle thoroughly first, using the water to be sampled.

Label the bottles immediately after sampling. Use permanent ink and good quality labels. Record the time, date, and location of sampling. Make sure each sample bottle is tightly closed.

A water sample should represent the water actually applied to plants. Thus, for example, you should collect water from sprinklers while they are operating. Similarly, the quality of water stored in ponds or lakes may change over time, particularly if the water has been recycled or if it is held for an extended period during hot weather, so sampling must take this into account. Water quality may also vary 
from season to season, so it may be appropriate to take samples for analysis at different times of year.

\section{INTERPRETING WATER QUALITY HAZARDS}

Clearly, water quality involves a complex set of factors and each irrigation water must be analyzed on an individual basis. Very few water sources are absolutely unsuitable for turfgrass irrigation. While you can use the discussion in this publication as a general guide to help you determine whether you have a turfgrass water quality problem, any determination of the precise nature and magnitude of that problem may require more than just water analysis. Climate, soil chemistry and physics, use patterns, and turf quality expectations all contribute both to any problem and to any potential remedies in turfgrass water quality.

\section{FOR MORE INFORMATION}

You'll find detailed information on many aspects of turfgrass and landscape care in these UC ANR publications:

Effluent Water for Turfgrass I rrigation, publication 21500

Evaluating Turfgrass Sprinkler Irrigation Systems, publication 21503

Managing Turfgrasses during Drought, publication 21499

Turfgrass Evapotranspiration Map: The Central Coast of California, publication 21491

Turfgrass Water Conservation, publication 21405

UC IPM Pest Management Guidelines for Turfgrass, publication 3365-T

Also of interest:

Grower's Weed Identification Handbook, publication 4030

Weeds of the West, publication 3350

To order these publications, visit our online catal og at http://anrcatalog.ucdavis.edu. You can also place orders by mail, phone, or fax, or request a printed catal og of publications, slide sets, and videos from

University of California

Division of Agriculture and Natural Resources

Communication Services

6701 San Pablo Avenue, 2nd Floor

Oakland, California 94608-1239

Telephone: 1-800-994-8849 or (510) 642-2431, FAX: (510) 643-5470

e-mail inquiries: danrcs@ucdavis.edu

Visit us on the World Wide Web: http://anrcatalog.ucdavis.edu 
An electronic version of this publication is available on the ANR Communication Services website at http://anrcatalog.ucdavis.edu.

\section{Publication 8009}

( 1999 by the Regents of the University of California, Division of Agriculture and Natural Resources. All rights reserved.

The University of California prohibits discrimination against or harassment of any person employed by or seeking employment with the University on the basis of race, color, national origin, religion, sex, physical or mental disability, medical condition (cancer-related or genetic characteristics), ancestry, marital status, age, sexual orientation, citizenship, or status as a covered veteran (special disabled veteran, Vietnam-era veteran or any other veteran who served on active duty during a war or in a campaign or expedition for which a campaign badge has been authorized).

University Policy is intended to be consistent with the provisions of applicable State and Federal laws.

Inquiries regarding the University's nondiscrimination policies may be directed to the Affirmative Action/Staff Personnel Services Director, University of California, Agriculture and Natural Resources, 1111 Franklin Street, 6th Floor, Oakland, CA 94607-5200 (510) 987-0096.

pr-12/99-WJC

ISBN 978-1-60107-189-7 